\title{
New and rare noctuid species (Lepidoptera, Noctuidae) in the fauna of the Republic of Moldova
}

\author{
Cristina ȚUgulea \& László RÁKOSY
}

\begin{abstract}
Summary: Data on 17 rare species of noctuids (Noctuidae) in the fauna of the Republic of Moldova are given in the present paper. The investigations were carried out during 2012-2020 in 26 sites throughout the Republic of Moldova. The genus Actebia STEPHENs, 1829 and the species Actebia praecox (LinnAeus, 1758) and Xylena solidaginis (HüBNER, 1803) are reported as new for the fauna of the Republic of Moldova. Thus, the number of noctuid species in the fauna of the Republic of Moldova reached 427 . The species: Acontia titania (EsPer, 1798), Aedophron rhodites (Eversmann, 1851), Periphanes delphinii (Linnaeus, 1758), Eucarta amethystina (HüBner, 1803), Dasypolia temples (Thunberg, 1792), Oxytripia orbiculosa (EsPer, 1799), Euxoa cos (HüBNER, 1824), Gortyna cervago (Eversmann, 1844), Meganephria bimaculosa (Linnaeus, 1758) and Cucullia argentea (Hufnagel, 1766) needs protection and conservation, so it is recommended according to IUCN criteria to be included in the next edition of the Red Book of the Republic of Moldova and the elaboration of concrete management measures.
\end{abstract}

Rezumat: Lucrarea prezintă 17 specii de noctuide (Noctuidae) rare în fauna Republicii Moldova. Investigațiile au fost efectuate în intervalul 2012-2020 în 26 situri de pe întreg teritoriul Republicii Moldova. Genul Actebia STEPHENS, 1829 este semnalat pentru prima data din Republica Moldova. Speciile Actebia praecox (Linnaeus, 1758) și Xylena solidaginis (HüBner, 1803) reprezintă taxoni noi pentru fauna Republicii Moldova. Astfel, numărul speciilor de noctuide din fauna Republicii Moldova se ridică la 427. Speciile Acontia titania (EsPer, 1798), Aedophron rhodites (Eversmann, 1851), Periphanes delphinii (Linnaeus, 1758), Eucarta amethystina (HüBner, 1803), Dasypolia templi (Thunberg, 1792), Oxytripia orbiculosa (EsPer, 1799), Euxoa cos (HüBNER, 1824), Gortyna cervago (Eversmann, 1844), Meganephria bimaculosa (Linnaeus, 1758) și Cucullia argentea (HufnaGel, 1766) sunt rare și localizate, necesitând protecție și conservare. Conform criteriilor IUCN se recomandă includerea speciilor menționate în următoarea ediție a Cărții Roșii a Republicii Moldova și elaborarea unor măsuri concrete de management.

Key words: Noctuidae, Republic of Moldova, new species, rare species, protected species.

\section{Introduction}

After regrouping the subfamily Catocalinae and Calpinae to the Erebidae family, the Noctuidae family, with about 12000 species is the second largest family of Noctuoidae in the world. According to the latest studies (Țugulea and Derjanschi 2015, Țugulea 2020) in the Republic of Moldova, the Noctuidae family consists of 425 species, taxonomically classified in 169 genera and 17 subfamilies: Plusiinae (23 species), Eustrotiinae (5), Acontiinae (6), Pantheinae (1), Dilobinae (1), Acronictinae (21), Metoponiinae (5), Cuculliinae (24), Oncocnemidinae (5), Amphipyrinae (7), Psaphidinae (5), Heliothinae (11), Condicinae (3), Bryophilinae (10), Xyleninae (141), Hadeninae (84) and Noctuinae (73 species). Given that neighboring countries recorded a much higher number of noctuid species (e.g. Romania with 557 [RAKOSY et al. 2021]), their number could increase in the coming years in the fauna of the Republic of Moldova.

Despite the fact, that noctuids are most often viewed only from the point of view of pests, as a result of the large number of published works on this subject, a number of factors have contributed to the decrease of the numbers of specimens in the populations, which has led to the increase of the number of endangered noctuid species (T,UGULEA 2020). In recent years we have witnessed an alarming decline in some species of butterflies and moths that a few decades ago were considered very common. The noctuids are as endangered as diurnal butterflies and face the same problems, such as intensification of agriculture, abandonment of traditional land use, changes in forest management and pollution of the environment.

There is a decrease in the number of specimens of noctuid populations not only of endangered species but also of those with harmful status. If on August 27 1971, the scientist M. Tkaci collected in Glodeni district for one night, at the with light trap 205 specimens of Anarta trifolii (HUFNAGEL, 1766) (TKACI 1977), then between 2012-2020, the number of individuals of this species has decreased extremely much. The scientist mentions that in the following year, the number of captured individuals increased. 
Comparing these data with the data obtained in the last eight years of studies following the systematic collection in two sites in the northern and central area of the Republic of Moldova, there is a decrease in the number of species, most specimens being collected in Brânzeni village (Edineț district) on the night of 24.06.2016 was 81 (T,Ugulea 2020).

The small number of noctuid species present on various Red Lists is due to the insufficient study of this group of insects, both nationally and internationally, which does not allow for risk assessment disappearance based on population distribution or status. Insufficient data and lack of information on the distribution, abundance, bioecological particularities classify many species of noctuids in an endangered category. It explains the status of extinct species (EX) attributed to many noctuids that have not been previously assessed and qualified in any category of endangered species. The same situation is attested in the Republic of Moldova. Before our investigations, there were no data on the endangered status of Noctuidae, and the Red Book of the Republic of Moldova does not mention a single species from the Noctuidae family.

We recommend adding some rare and endangered Noctuidae species to the Red Book of the Republic of Moldova and the National Operational List in order to ensure protection and the necessary information for the population and authorities.

\section{Material and Methods}

The materials of this work were obtained during the years 2012-2020 from different natural and anthropic habitats of the Republic of Moldova.

The noctuid collections were carried out from March to November on 26 sites in the north, center and south of the Republic of Moldova, distributed the entire territory and all habitats suitable for moths (fig. 1).

The noctuids were collected by the following methods: manual collection, with the entomological net, at the standard electric lamp $(100 \mathrm{~W})$, with the help of an illuminated white cloth and by installing ultraviolet and white light traps. The entomological traps with white and ultraviolet light were located at a distance of $15 \mathrm{~m}$ from each other. The collection was carried out with a periodicity of two days per week.

The nomenclature and classification was given according to FiBIGER and HACKER (2005) and WitT and RonKaY (2011). For species identification we have used the works by RÁKOSY (1996), KLYUCHKO (2006), the 13 volumes of Noctuidae Europeae and the Lepiforum website (http://www.lepiforum.de). We have also made genitalia examination for species that are difficult to determine.

\section{Results and Discussions}

The paper presents 17 species of noctuids (Noctuidae) rare in the fauna of the Republic of Moldova, taxonomically classified in 8 subfamilies: Acontiinae (1 species), Heliothinae (2), Condicinae

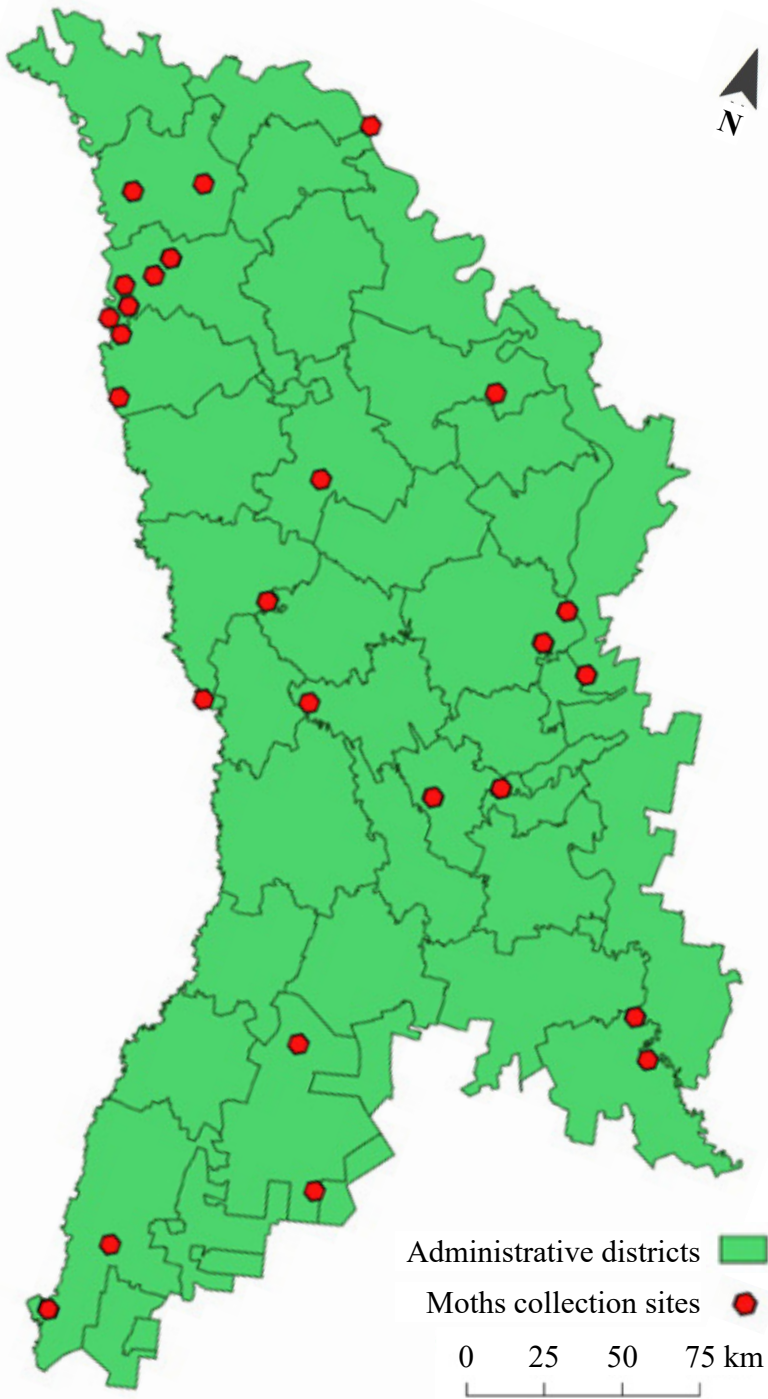

Fig. 1. Diagram of the location of noctuid collection sites on the territory of the Republic of Moldova.

(1), Xyleninae (5), Noctuinae (5), Oncocnemidinae (1) Psaphidinae (1) and Cuculliinae (1 species). The data presented in the paper are mostly the first or second report of noctuid species in the fauna of the Republic of Moldova.

The genus Actebia Stephens, 1829 with the species A. praecox (Linnaeus, 1758) and Xylena solidaginis (HÜBNER, 1803) represent new taxa for the country's fauna. Thus, the number of noctuid species in the fauna of the Republic of Moldova reached 427.

The species: Acontia titania (ESPER, 1798), Aedophron rhodites (EversmanN, 1851), Periphanes delphinii (Linnaeus, 1758), Eucarta amethystina (HüBNer, 1803), Dasypolia templi (ThunberG, 1792), Oxytripia orbiculosa (ESPER, 1799), Euxoa cos (HÜBNER, 1824), Gortyna cervago (EvERSMANN, 1844), Meganephria bimaculosa (Linnaeus, 1758) and Cucullia argentea (HufNagel, 1766) needs protection and conservation, so it is recommended according to IUCN criteria to be included in the next edition of the Red Book of the Republic of Moldova. The other species mentioned in the paper need to be included in the National Operational List of the Republic of Moldova and further directed research 
for better knowledge. In the list of Noctuidae moths shown below, we mention the most important species, their records, some ecological and distribution data as well the conservation status in some European countries.

New taxa for the fauna of the Republic of Moldova are marked with an asterisk $(*)$.

\section{Familia Noctuidae LATREILLE, 1809}

\section{Subfamilia Acontiinae}

\section{Acontia titania (ESPER, 1798) (fig. 2)}

Collected material: the species was reported in the Forest Nature Reserve "Cobîleni" (Orhei district) on July 31 2016, 1 spec. Although the species is mentioned by the site https://fauna-eu, the specimen collected in the "Cobîleni" Reserve is the only confirmatory evidence of the presence on the territory of the Republic of Moldova.

Geographical spread: central-asian-mediterranean element.

Ecological preference: xero-thermophilous species.

Protection and conservation: Acontia titania is a rare species in the fauna of the Republic of Moldova. In Romania Acontia titania has the status of a vulnerable species (VU) (RÁKosY et al. 2003).

\section{Subfamilia Heliothinae}

\section{Aedophron rhodites (EVERSMANn, 1851) (fig. 3)}

Collected material: the species was reported for the first time in the fauna of the Republic of Moldova in the "Cobîleni" Reserve, June 25 2016, 1 spec.

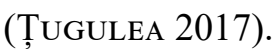

Geographical spread: central-asian-mediterranean element.

Ecological preference: xero-thermophilous species.

Protection and conservation: it is very rare species in the fauna of the Republic of Moldova. It is included in the Red List of Romania with endangered critical status (CR) (RÁkosy et al. 2003, RÁKosy et al. 2021). In Ukraine it is included in the list of species that need protection and conservation, reported in several sites in the southeastern region (KLYUCHKo 2006). The species Aedophron rhodites needs protection and conservation, so it is proposed to be included in the next edition of the Red Book of the Republic of Moldova.

Periphanes delphinii (Linnaeus, 1758) (fig. 4) Collected material: on the territory of the Republic of Moldova there were three records of the species Periphanes delphinii. The first time in the fauna of the Republic of Moldova was reported in Chisinau on April 23 1903, 1 spec. (Miller and Zubovschi 1908). Later, in Ivancea village (Orhei district), between August 07 and September 161964 four more specimens were collected by the naturalist $\mathrm{R}$.
Stepanov. The most recent report took place in the “Cobîleni” Reserve, July 15 2016, 1 spec. (Țugulea and ȚugulEa 2019b).

Geographical spread: west-asian-mediterranean element.

Ecological preference: xero-thermophilous species.

Protection and conservation: Periphanes delphinii is an endangered species both in the Republic of Moldova and in many European countries (T,UGULEA 2020). In Romania it has the status of endangered species (EN) (RÁKosy et al. 2003, RÁKosy et al. 2021). In Ukraine it is included in the Red Book and in the list of species that need protection and conservation (AKIMOVA 2009, KLYUCHKo 2006). The species is also included in the Red List of Hungary with endangered status (https:// lepidoptera.eu/). In Germany and the Czech Republic it has extinct species status (EX) (WOLF and HACKER 2003, Herja et al. 2017). The species Periphanes delphinii needs protection and conservation, so it is recommended to be included in the Red Book of the Republic of Moldova.

\section{Subfamilia Condicinae}

\section{Eucarta amethystina (HüBNER, 1803) (fig. 5)}

Collected material: the only report on the territory of the Republic of Moldova was in the "Cobîleni" Reserve, on August 19 2016, 1 spec. (T,UGulEA and ȚUGulea 2019a).

Geographical spread: euro-asian element.

Ecological preference: thermo-hygrophilous species. Protection and conservation: it is very rare species in the fauna of the Republic of Moldova. In Romania it has the status of a vulnerable species (RÁKosY et al. 2003, RÁKosy et al. 2021). In Ukraine it was reported only in the northwestern region of the country (KLYUChKo 2006). In Germany the species has endangered critical status (CR) (WOLF and HACKER 2003). The species Eucarta amethystina needs protection and conservation, so it is recommended to be included in the Red Book of the Republic of Moldova.

\section{Subfamilia Xyleninae}

\section{Dasypolia templi (ThUnBerg, 1792) (fig. 6)}

Collected material: the species was reported in the "Cobîleni" Reserve on October 17, 23 2016, 2 specs., being the only report of the species on the territory of the Republic of Moldova (TUGulea 2017).

Geographical spread: euro-asian element.

Ecological preference: meso-xero-thermophilous species.

Protection and conservation: in Romania and Germany Dasypolia templi has the status of endangered species (EN) (RÁKosy et al. 2003, Wolf and HACKer 2003).

Oxytripia orbiculosa (ESPER, 1799) (fig. 7)

Collected material: the first report on the territory 
of the Republic of Moldova happen in the Ivancea village (Orhei district) on October 20 1970, 1 spec., leg. R. Stepanov. Later, Oxytripia orbiculosa was collected in the "Cobîleni" Reserve, on October 11 2017, 1 spec.

Geographical spread: euro-asian element.

Ecological preference: xero-thermophilous species, prefers xero-thermophyte habitats near a running water source (RÁKOSY 1996).

Protection and conservation: very rare species in the fauna of the Republic of Moldova. In Romania it has the status of critically endangered species (CR) (RÁkosy et al. 2003). In Ukraine it was reported only near the Donetsk (KLYuchKo 2006). Oxytripia orbiculosa is also included in the Hungarian Red List (https://lepidoptera.eu/). The species needs to be included in the next edition of the Red Book of the Republic of Moldova.

\section{Gortyna cervago (EvERSMANN, 1844) (fig. 8)}

Collected material: the species was reported for the first time on the territory of the Republic of Moldova in Chisinau on September 14 1922, $1 \mathrm{spec}$. (Miller et al. 1932 ). Later it was collected in Chisinau, September 27 1932, 1 spec.; Bahmut village (Ungheni district), September 5-14 1961, 2 specs., leg. S. Plugaru and Ivancea village (Orhei district), September 28 1971, 1 spec., leg. R. Stepanov. After a period of several decades, the species Gortyna cervago was reported in the "Cobîleni" Reserve, in period August 31 and October 07 2016, 4 specs.; September 23 2017, 1 spec. and August 12 2018, 1 spec. (Țugulea 2020). Geographical spread: ponto-caspian element.

Ecological preference: xero-thermophilous species. Protection and conservation: the species was reported only in the central area of the Republic of Moldova. In Romania, the species Gortyna cervago was considered CR (RÁkosy et al. 2003), but was downgraded to NT in the new edition of the Red List (RÁKOsY et al. 2021). In Ukraine it has been reported only in a few sites in the southern region of the country (KLYUCHKO 2006).

\section{Episema tersa (DENIS \& SCHIFFERMülLER, 1775)} (fig. 9)

Collected material: the presence of the species on the territory of the Republic of Moldova until our studies was mentioned by the site https://fauna-eu.org/. These data were confirmed in 2016, in the "Cobîleni" Reserve where 13 individuals were collected on September 072016 and September 17 2017. In other parts of the country, Episema tersa was not reported. Geographical spread: ponto-caspian element.

Ecological preference: xero-thermophilous species. Protection and conservation: In Romania, the species Episema tersa was considered VU (RÁKosy et al. 2003), but was downgraded to LC/NT in the new edition of the Red List (RÁKosY et al. 2021). In the Czech Republic Episema tersa has the status of vulnerable species (VU) (HerJa et al. 2017).
*Xylena solidaginis (HüBNER, 1803) (fig. 10)

Collected material: is a new species for the fauna of the Republic of Moldova, reported in the "Codrii" Scientific Reserve, Lozova village (Strășeni district), July 262019 , 1 spec.

Geographical spread: holarctic element.

Ecological preference: hygrophilous species.

Protection and conservation: in Romania Xylena solidaginis has the status of a near threatened (NT) (RÁKosy et al. 2021).

\section{Subfamila Noctuinae}

\section{Euxoa cos (HüBNER, 1824) (fig. 11)}

Collected material: the only report on the territory of the Republic of Moldova was in the "Cobîleni" Reserve, September 17 2016, 1 spec. (T,ugulea 2019).

Geographical spread: west-asian-mediterranean element.

Ecological preference: xero-thermophilous species.

Protection and conservation: is rare species in the fauna of the Republic of Moldova.

\section{Euxoa birivia (DENIS \& SCHIFFERMÜLLER, 1775)} (fig. 12)

Collected material: the only report on the territory of the Republic of Moldova was in the "Cobîleni" Reserve, September 17 2016, 1 spec. (Țugulea 2019).

Geographical spread: euro-asian element.

Ecological preference: mesophilous species.

Protection and conservation: In Romania it has data deficient (DD) status. In Ukraine the species has been recorded in two western regions and in the south of the Crimean peninsula (KLYUCHKo 2006). The species Euxoa birivia is included in the Hungarian Red List (https://lepidoptera.eu/).

Xestia sexstrigata (HAworTh, 1809) (fig. 13)

Collected material: the species was first reported in

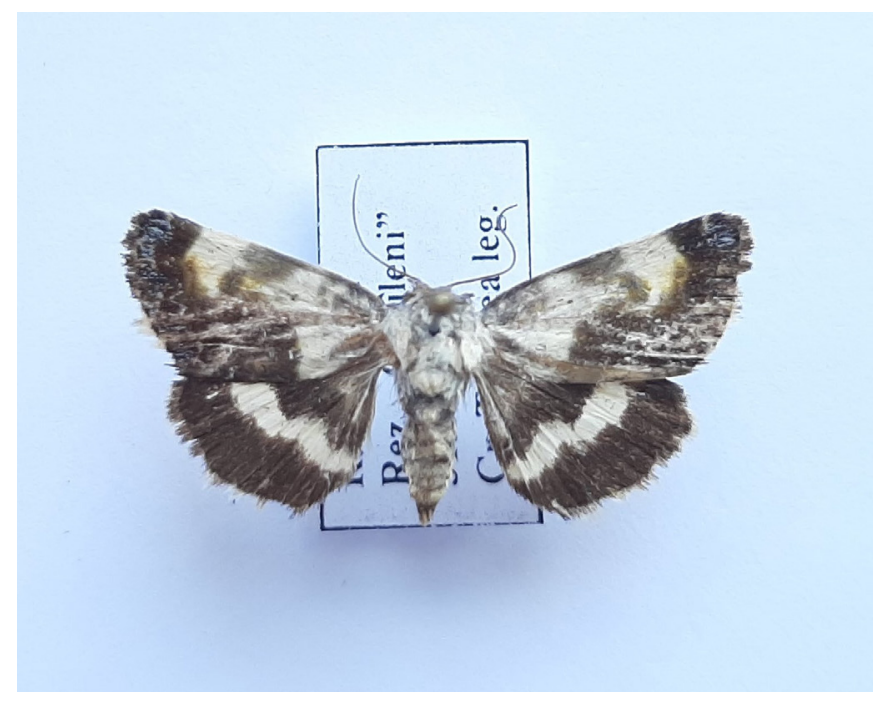

Fig. 2. Acontia titania (ठ), 31.07.2016, Republic of Moldova, Forest Nature Reserve "Cobîleni”" (Orhei district). 


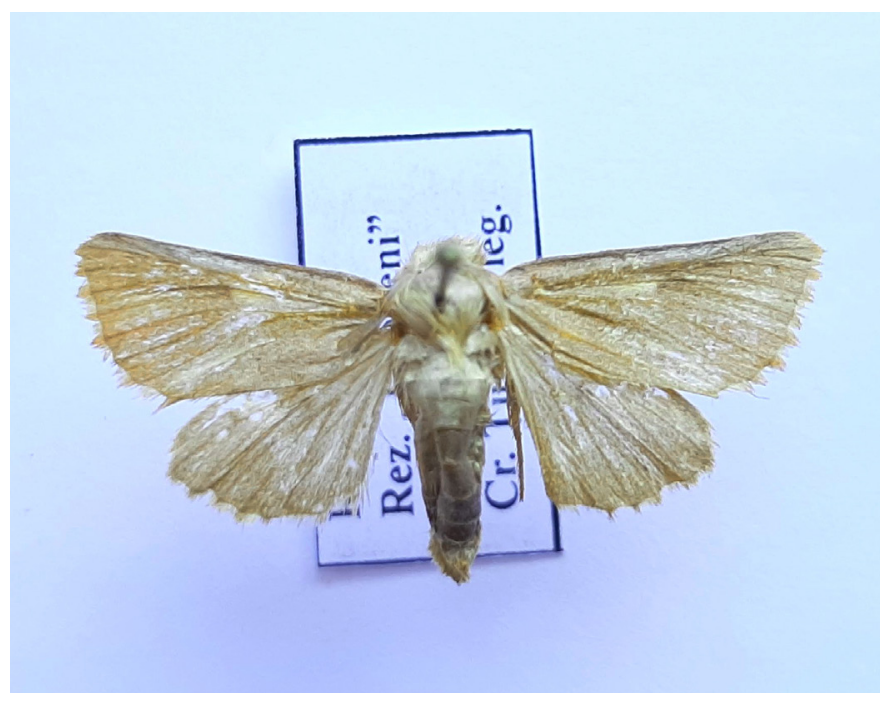

Fig. 3. Aedophron rhodites (ð), 25.06.2016, Republic of Moldova, "Cobîleni" Reserve (the pink color disappeared due to the immobilization solution).

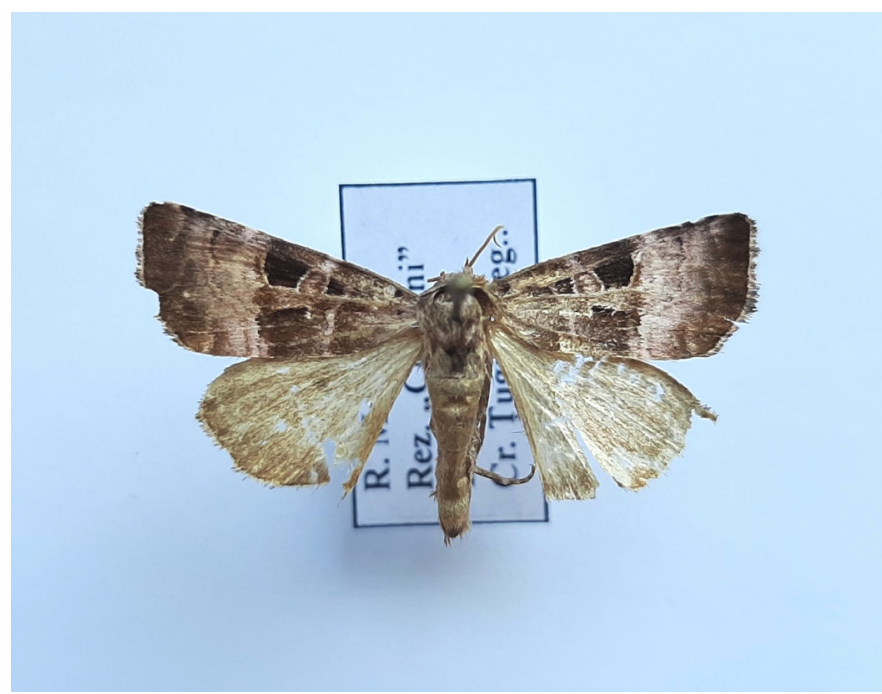

Fig. 5. Eucarta amethystina (ठ), 19.08.2016, Republic of Moldova, "Cobîleni”" Reserve

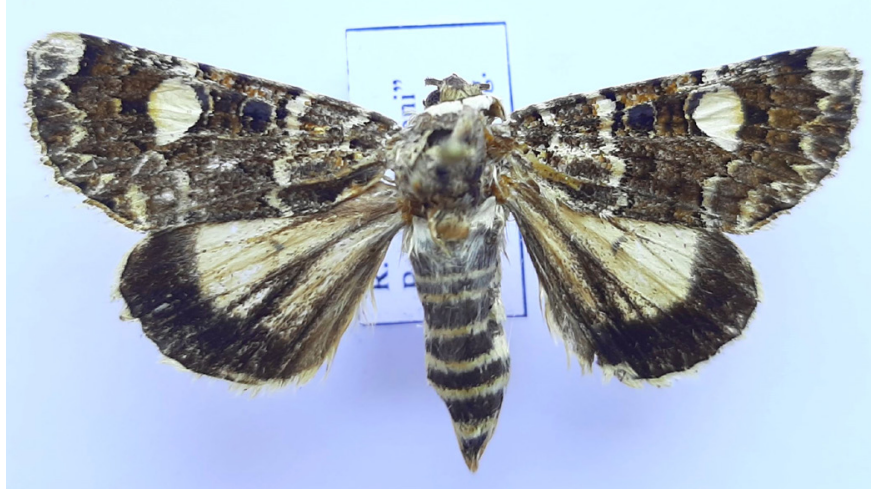

Fig. 7. Oxytripia orbiculosa, 11.10.2017, Republic of Moldova, "Cobîleni” Reserve

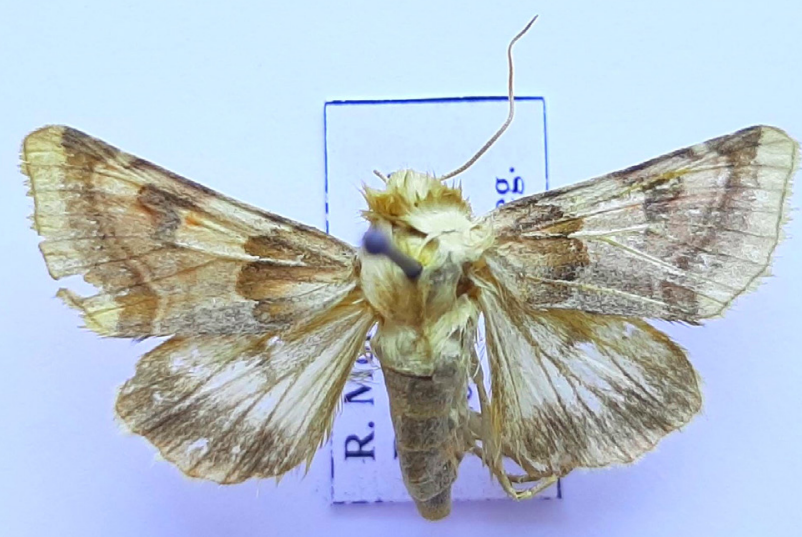

Fig. 4. Periphanes delphinii (ð), 15.07.2016, Republic of Moldova, "Cobîleni”" Reserve.

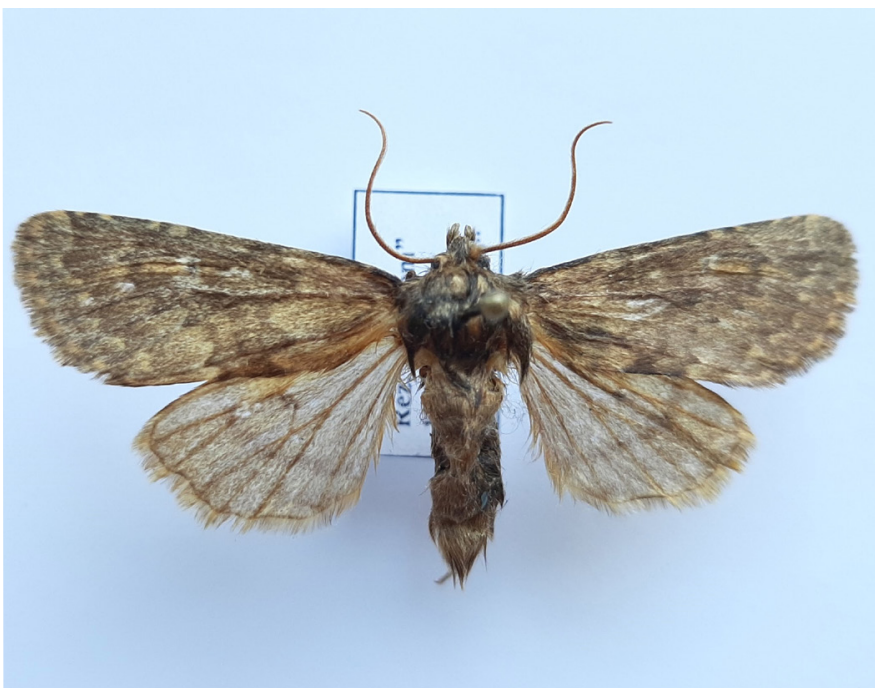

Fig. 6. Dasypolia templi (q), 17.10.2016, Republic of Moldova, "Cobîleni” Reserve

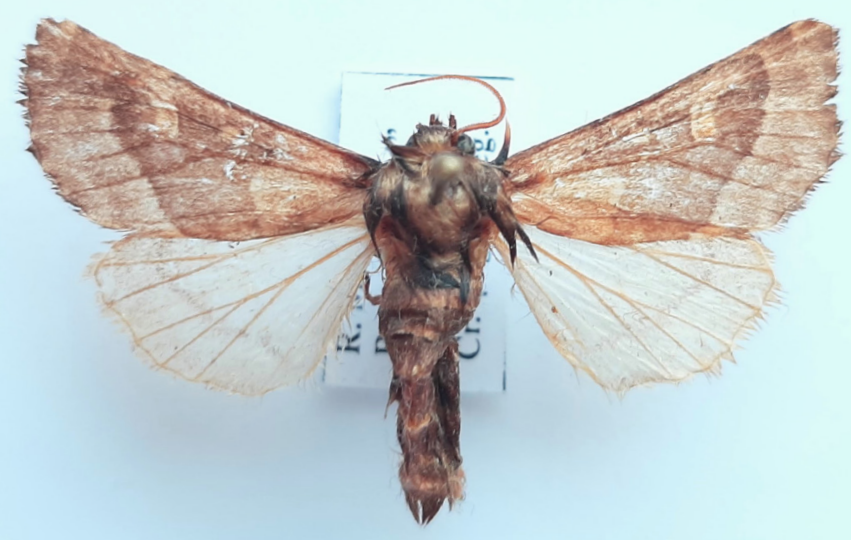

Fig. 8. Gortyna cervago (ð), 07.10.2016, Republic of Moldova, "Cobîleni”" Reserve. 


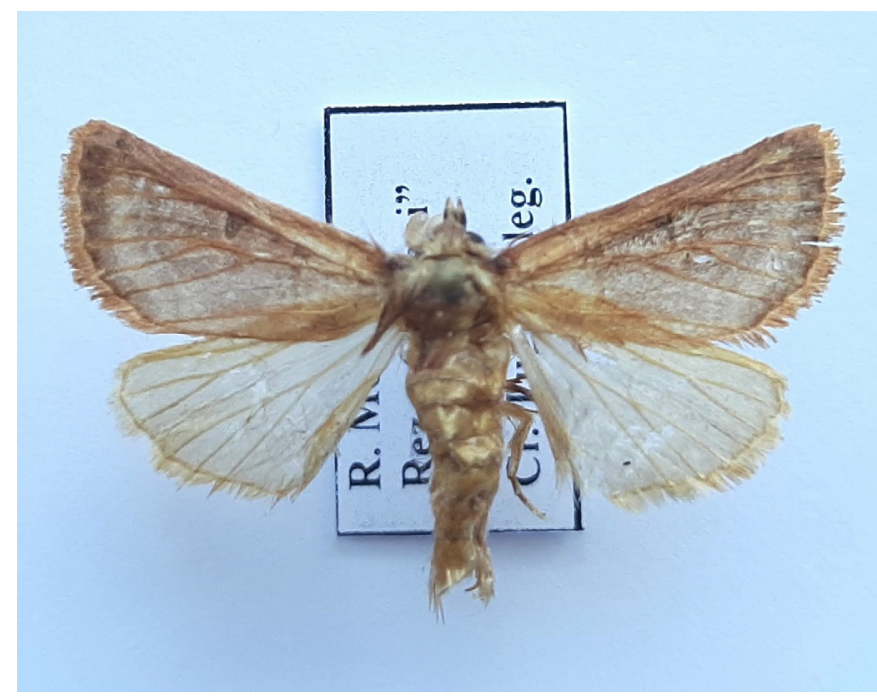

Fig. 9. Episema tersa (ð), 29.09.2016, Republic of Moldova, "Cobîleni” Reserve.

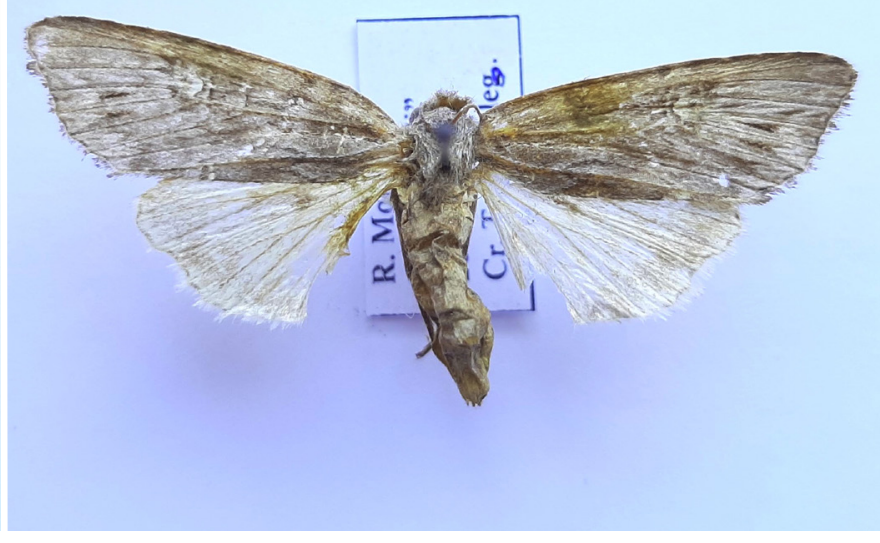

Fig. 10. Xylena solidaginis (), 26.07.2019, Republic of Moldova, "Codrii" Scientific Reserve
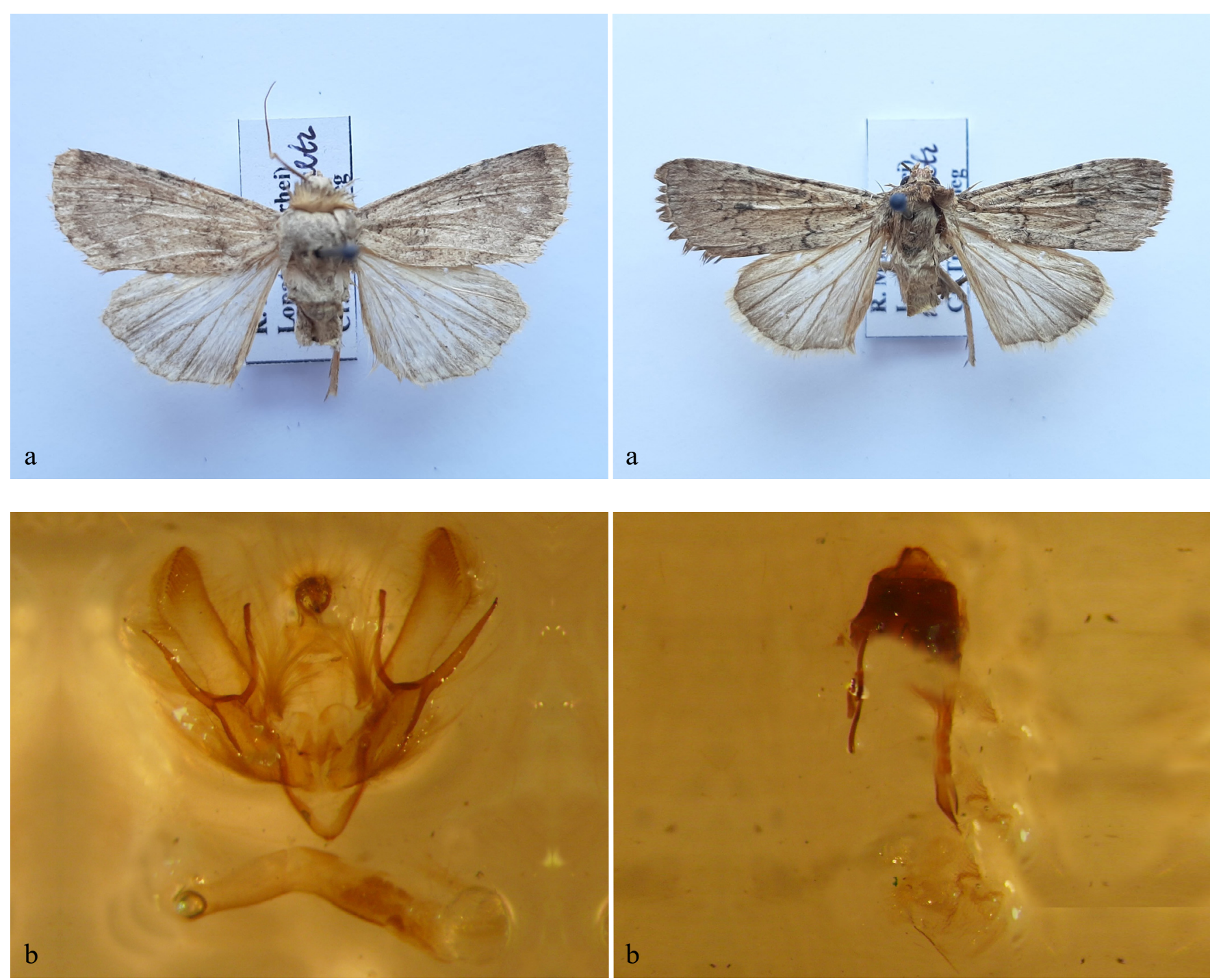

Fig. 11. Euxoa cos, 17.09.2016, Republic of Moldova, “Cobîleni” Reserve, a. - imago (ðへ); b. - the genital armature with the detached aedagus (Gen. prep. C. T,ugulea).

Fig. 12. Euxoa birivia, 17.09.2016, Republic of Moldova, "Cobîleni" Reserve, a. - imago (q); b. - the genital armature (ㅇ) (Gen. prep. C. Țugulea). 


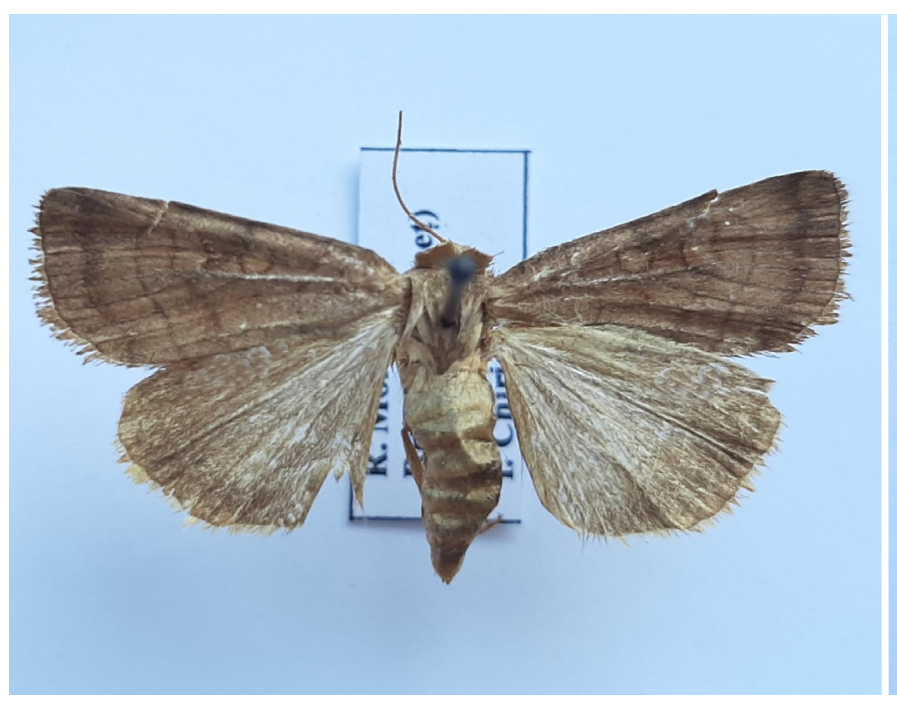

Fig. 13. Xestia sexstrigata (q), 02.09.2016, Republic of Moldova, Brînzeni village (Edineț district).

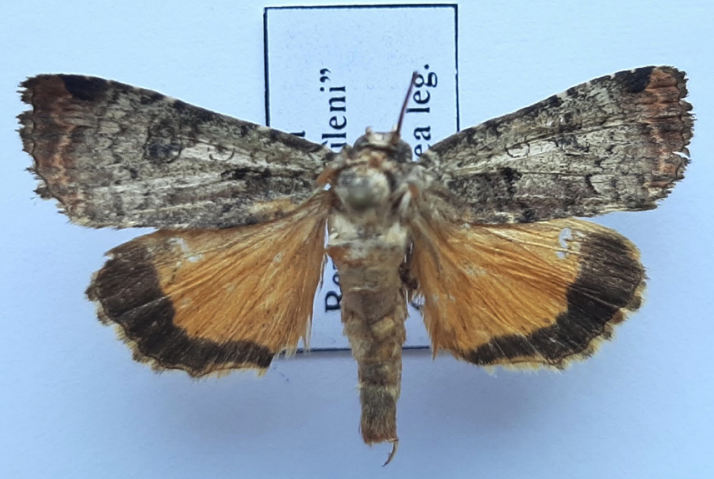

Fig. 14. Epilecta linogrisea (ठึ), 27.07.2016, Republic of Moldova, "Cobîleni" Reserve.

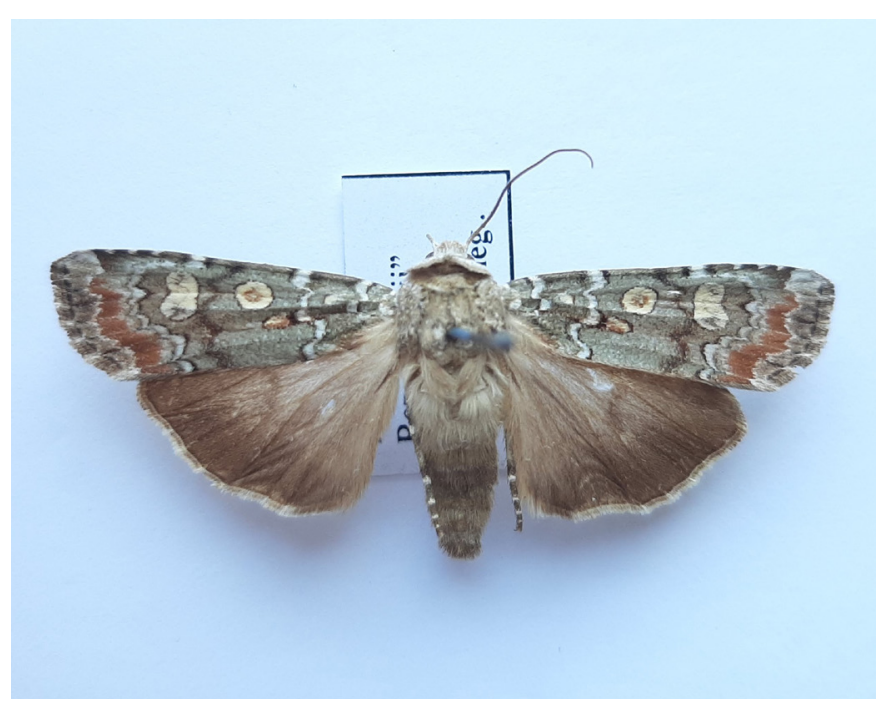

Fig. 15. Actebia praecox, 26.07.2019, Republic of Moldova, "Codrii" Scientific Reserve

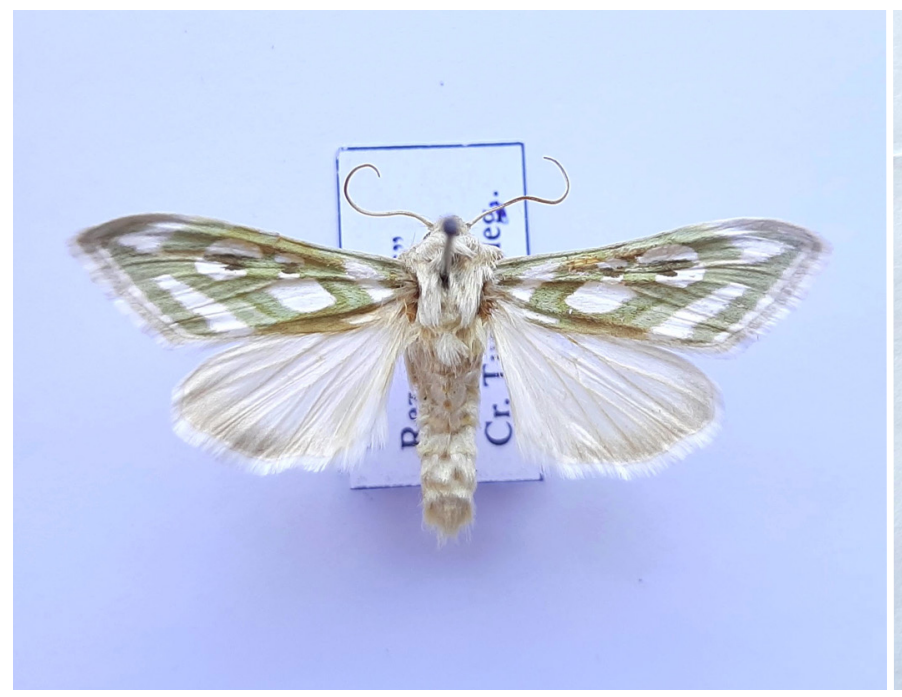

Fig. 17. Cucullia argentea (ð), 26.07.2019, Republic of Moldova, "Codrii" Scientific Reserve
Fig. 16. Calophasia opalina (q), 20.07.2019, Republic of Moldova, "Cobîleni" Reserve

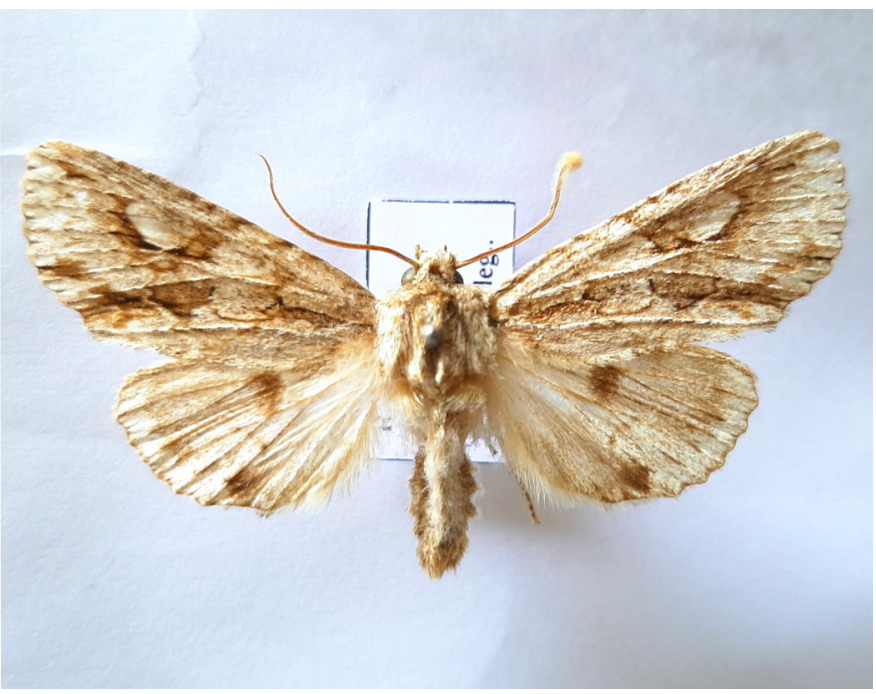

Fig. 18. Meganephria bimaculosa (ð), 26.09.2020, Republic of Moldova, "Codrii" Scientific Reserve 
the fauna of the Republic of Moldova in Brînzeni (Edineț district) on September 02 2016, 1 spec., leg. I. Chiriac (T,ugulea 2017).

Geographical spread: atlanto-mediterranean element. Records from Austria, Hungary, Ukraine and the Republic of Moldova collected in the last 30 years suggest that Xestia sextrigata is extending its range towards South-Eastern Europe (RÁKOSY and RÁKOSY 2020).

Ecological preference: meso-hygrophilous species.

Protection and conservation: the species is included in the Hungarian Red List (https://lepidoptera.eu/).

\section{Epilecta linogrisea (DENIS \& SCHIFFERMÜLLER, 1775)}

(fig. 14)

Collected material: the species was reported for the first time on the territory of the Republic of Moldova in Strășeni, August 16 1931, 1 spec. and Chișinău, August 25 1931, 3 specs., leg. N. Zubovschi. Later, after 85 years, it was reported in the "Cobîleni" Reserve on July 27 and September 11 2016, 2 specs. Geographical spread: central-asian-mediterranean element.

Ecological preference: xero-thermophilous species. Protection and conservation: is rare species in the fauna of the Republic of Moldova. In Romania and Germany it has the status of a near threatened species (NT) (RÁKosy et al. 2021, WOLF and HACKER, 2003).

\section{*Actebia praecox (LINNAEUs, 1758) (fig. 15)}

Collected material: new species for the fauna of the Republic of Moldova, reported in the "Codrii" Reserve, July 26 2019, 1 spec.

Răspândire: euro-asian element.

Ecological preference: mesophilous species.

\section{Subfamilia Oncocnemidinae}

\section{Calophasia opalina (ESPER, 1794) (fig. 16)}

Collected material: the species was first reported in the fauna of the Republic of Moldova in Chişinău at the beginning of the last century: May 15 1924, 2 specs.; June 6, August 26 1934, 2 specs.; May 24 1935, 1 spec.; August 31 1938, 1 spec. (Derjanschi et al. 2016). Later it was reported in Ivancea village (Orhei district), August 18 1975, 1 spec., leg. R. Stepanov and in the "Cobîleni" Reserve, July 20 2019, 1 spec. Geographical spread: central-asian-mediterranean element.

Ecological preference: xero-thermophilous species. Protection and conservation: the species is rarely found in the fauna of the Republic of Moldova.

\section{Subfamilia Cucullinae}

\section{Cucullia argentea (HufNAGEL, 1766) (fig. 17)}

Collected material: the species was first reported in the fauna of the Republic of Moldova in Ivancea village (Orhei district), in July 1963, 1 spec., leg.
R. Stepanov. Later, it was collected in the "Codrii" Reserve, July 26 2019, 1 spec.

Geographical spread: euro-asian element.

Ecological preference: mesophilous species.

Protection and conservation: the species Cucullia argentea is rarely found on the territory of the Republic of Moldova. In Romania it has the status of a vulnerable species (VU) (RÁKosy et al. 2003) and data deficient (DD) in the new edition of the Red List (RÁKosy 2021). The species is also protected in Ukraine and Germany with endangered species status (EN) (AKimova 2009, Wolf and Hacker 2003).

\section{Subfamilia Psaphidinae}

Meganephria bimaculosa (LinNAEUs, 1758) (fig. 18) Collected material: the first time in the fauna of the Republic of Moldova the species Meganephria bimaculosa was reported in Bender, October 13 1923, 2 specs., later in Chişinău, October 01 1925, 1 spec.; October 01 1932, 1 spec. and Bularda village (Călărași district), September 23, 24 1935, 2 specs., leg. N. Zubovschi. The most recent report happen in the "Codrii" Reserve, September 26 2020, 1 spec.

Geographical spread: central-asian-mediterranean element.

Ecological preference: thermo-meso-hygrophilous species.

Protection and conservation: the species Meganephria bimaculosa is rarely found on the territory of the Republic of Moldova. In Germany, the species has the status of critically endangered species (CR) (WOLF and HACKER 2003). In Romania the species was regarded as CR (RÁkosy et al. 2003) but entered in the new edition of the Red List as NT et al 2021(RÁkosy et al 2021). This species needs protection and conservation, so it is recommended to be included in the Red Book of the Republic of Moldova.

\section{Conclusions}

The genus Actebia StePhens, 1829 and the species Actebia praecox (Linnaeus, 1758) and Xylena solidaginis (HÜBNER, 1803) represent new taxa for the country's fauna. Thus, the number of noctuid species in the fauna of the Republic of Moldova reached 427.

The noctuid species: Acontia titania (ESPER, 1798), Aedophron rhodites (Eversmann, 1851), Periphanes delphinii (Linnaeus, 1758), Eucarta amethystina (HüBner, 1803), Dasypolia templi (Thunberg, 1792), Oxytripia orbiculosa (ESPER, 1799), Euxoa cos (HüBNER, 1824), Gortyna cervago (EvERSMANn, 1844), Meganephria bimaculosa (Linnaeus, 1758) and Cucullia argentea (HufNagel, 1766) needs protection and conservation, so it is recommended to be included in the next edition of the Red Book of the Republic of Moldova. 


\section{Acknowledgements}

We highly grateful to Professor Valeriu Derjanschi for coordinating research and valuable advice regarding the manuscript. We also thank dr. Andrian Tugulea, for his active involvement in moth collection.

The research was carried in the project 20.80009.7007.02. from the State program of the Institute of Zoology.

\section{References}

Akimova I. A. (Ed.) (2009) Red Book of Ukraine. Global consulting". Kiev, 624 pp. (in Ucranian)

Derjanschi V., Baban E., Calestru L., Stahi N. and Twugulea C. (2016) Catalogue of the N. Zubowsky entomological collection. Chișinău, Edit. Bons Offices, 296 pp.

FIBIGER M. (1990) Noctuidae I. Noctuidae Europeae vol.1. Entomological Press. Sorø, Dänemark.

FIBIGER M. (1993) Noctuidae II. Noctuidae Europeae vol. 2. Entomological Press. Sorø, Dänemark.

Fibiger M. and HACKer H. (2005) Systematic List of the Noctuidae of Europe (Notodontidae, Nolidae, Arctiidae, Lymantriidae, Erebidae, Micronoctuidae, and Noctuidae). Esperiana. Buchreihe zur Entomologie 11: 93-205.

Fibiger M., Ronkay L., Yela J. L. and A Zilli (2010) Noctuidae Europaeae vol. 12. Entomological Press. Sorø, Dänemark.

Hacker H., Ronkay L. and M. Hreblay (2002) Hadeninae I. Noctuidae Europaeae vol 4. Entomological Press Sorø.

Hejda R., FARKač J. and Сновот K. (2017) Červený Seznam Ohrožených Druhů České Republiky Bezobratlí. [Red List of Endangered Invertebrates Species of the Czech Republic], Praha. pp. 213-216. (in Czech)

KLyuchio Z. (2006) [The noctuids of Ukraine. Series Natura of Ukraine]. Kiev. 248 pp. (in Russian)

LEPIDOPTERA MUNDI (formerly European Butterflies and Moths), https://lepidoptera.eu, accessed in 2016-2020.

LEPIFORUM: Bestimmung von Schmetterlingen (Lepidoptera) und ihren Präimaginalstadien, http:// www.lepiforum.de, accessed in 2016-2020.

Miller E., Zubovschi N. (1908) [Materials on the Entomological Fauna of Bessarabia. Lepidoptera (Macrolepidoptera). Works of the Bessarabian Society of Natural Scientists and Amateurs of Natural History]. Edit. „Tipo-Litografia”, Chişinău, 3: 410-425. (in Russian)

Miller E., Zubovschi N. and Ruscinschi A. (1929) Materiale pentru fauna entomologică din Basarabia. Macrolepidoptera. Suplimentul III. [Materials for entomological fauna from Bessarabia. Macrolepidoptera. Supplement III]. Buletinul Muzeului Naţional de Istorie Naturală 2-3: 97-130. (in Romanian)

Miller E., Zubowsky N. and Ruschtschinsky A. (1932) Materilien zur kenntnis der entomologischen fauna Bessarabiens. Macrolepidoptera. Nachtrag IV. [Materials for a knowledge of the entomological fauna of Bessarabia. Macrolepidoptera. Supplement IV]. Buletinul Muzeului Național de Istorie Naturală 4: 2538. (in German)

RÁkosy L. (1996) Die Noctuiden Rumäniens. [The Noctuids of Romania]. Staphia, Linz, 648 pp. (in German)
RÁKosy L. and RÁKosy D. (2020) Xestia sextrigata (Haworth, 1809) (Lepidoptera, Noctuidae) a new species expanding into Romania. Entomologica romanica 24: 37-40.

Rákosy L., GoIA M. and Kovács Z. (2003) Catalogul Lepidopterelor României/Verzeichnis der Schmetterlinge Rumäniens/Catalogue of the Lepidoptera of Romania. Societatea Lepidopterologică Romană, Cluj-Napoca. 447 pp.

Rákosy L., Corduneanu C., Crişan A., Dincă V., KovÁcs S., StĂNescu M., SzéKely L. 2021 In RÁKosy L. (ed.). Lista roșie a fluturilor din România. Romanian Red List of Lepidoptera. Presa Universitară Clujeană, 187 pp.

TKACI M. (1977) [The noctuids and control methods]. Chișinău, Edit. „Cartea Moldovenească”, 108 pp. (in Russian)

Țugulea C. (2017) Specii noi de Noctuide (Lepidoptera, Noctuidae) în fauna Republicii Moldova. [New species of Noctuids (Lepidoptera, Noctuidae) in the fauna of the Republic of Moldova]. International symposium „Actual problems of zoology and parasitology: Achievements and prospects" 13 october 2017. Chișinău, p. 347. (in Romanian)

Țugulea C. (2019) Specii din genul Euxoa Hubner, 1821 (Lepidoptera, Noctuidae) - noi pentru fauna Republicii Moldova. [Species of the genus Euxoa Hubner, 1821 (Lepidoptera, Noctuidae) - new for the fauna of the Republic of Moldova]. Buletinul Academiei de Științe a Moldovei. Științele Vieții 1 (337): 121-124. (in Romanian)

Țugulea C. and DerJanschi V. (2015) Istoricul studiului noctuidelor (Lepidoptera, Noctuidae) în Republica Moldova. [History of the study of noctuids (Lepidoptera, Noctuidae) in the Republic of Moldova]. Buletin Științific. Revistă de Etnografie. Științele Naturii și Muzeologie. Serie nouă. Fascicula Științele Naturii. Chișinău 22 (35): 59-81. (in Romanian)

ȚuguleA C. and ȚuguleA A. (2019a). Noctuidele din subfamilia Condicinae (Lepidoptera, Noctuidae) semnalate în fauna Republicii Moldova. [Noctuids from the subfamily Condicinae (Lepidoptera, Noctuidae) reported in the fauna of the Republic of Moldova]. Buletin Științific. Revistă de Etnografie, Științele Naturii și Muzeologie. Serie nouă. Fascicula Științele Naturii. Chișinău 30 (43): 51-54. (in Romanian)

Țugulea C. and T,ugulea A. (2019b). Periphanes delphinii (Linnaeus 1758) (Lepidoptera, Noctuidae) - a threatened species in the fauna of the Republic of Moldova. Simpozionul național cu participare internațională "Environment \& Progress" Ediția a XII- $a$, Cluj-Napoca 15 noiembrie 2019. Book of abstract, Cluj-Napoca, p. 62.

ȚUgulea C. (2020) Starea actuală și importanța fluturilor din familia Noctuidae (Lepidoptera) in ecosistemele naturale și antropizate din Republica Moldova. [Current status and importance of butterflies of the Noctuidae family (Lepidoptera) in natural and anthropized ecosystems in the Republic of Moldova]. (PhD Thesis). Teză de doctorat. Ministerul Educației, Culturii și Cercetării, Universitatea de Stat "Dimitrie Cantemir", Chișinău. Nr. manuscris: CZU: 595.786-19(478) (043.2). (in Romanian).

Witt Th.J., Ronkay L. (eds.) (2011) Lymantriinae- 
Arctiinae, including Phylogeny and Check List of the Quadrifid Noctuoidea of Europe. Noctuidae Europaeae. Vol. 13. Entomological Press, Sorø, Dänemark.

Wolf B.W. and Hacker H. (2003) Rote Liste gefährdeter Nachtfalter (Lepidoptera: Sphinges, Bombyces,
Noctuidae, Geometridae) Bayerns. [Red list of endangered moths (Lepidoptera: Sphinges, Bombyces, Noctuidae, Geometridae) of Bavaria]. Bayerns, Das Bayerische Landesamt für Umwelt 166: 223-233. (in German).
Cristina Țugulea

The Institute of Zoology

Academiei Str. 1, Chișinău,

Republic of Moldova

E-mail: tuguleacristy@yahoo.com
László RÁKOSY

Department of Taxonomy and Ecology Babeș-Bolyai University, Clinicilor 5-7

Cluj-Napoca, RO-400006, Romania

E-mail: laszlo.rakosy@ubbcluj.ro
Received: 01.07.2021

Accepted: 01.08.2021

Published online: 31.12 .2021

Article number: ER25202101

doi: 10.24193/entomolrom.25.1 